\title{
TOLERABILITY OF BEVACIZUMAB IN ELDERLY PATIENTS WITH OVARIAN CANCER: AN EXPERIENCE FROM THE DEPARTMENT OF GYNECOLOGIC ONCOLOGY IN THE UNIVERSITY HOSPITAL CENTRE ZAGREB
}

\author{
KRISTINA KATIĆ, VIŠNJA MATKOVIĆ, JOŠKO LEŠIN, \\ GORAN VUJIĆ and ANTE ĆORUŠIĆ \\ Department of Gynecologic Oncology, Clinical Department of Gynecology and Obstetrics, \\ University Hospital Centre Zagreb, Croatia
}

\section{Summary}

Introduction: Bevacizumab is a recombinant humanized anti-VEGF monoclonal antibody. It is an effective treatment for epithelial ovarian cancer, both in primary and recurrent disease. The incidence of ovarian cancer increases with advancing age. Despite the high prevalence of the ovarian cancer in elderly, the management of these patients is often less aggressive than in younger patients. In Croatia, from February 2017, we have opportunity to treat patients with epithelial ovarian, fallopian tube, or primary peritoneal cancer with bevacizumab in the first-line and second-line settings. Our aim was to investigate the safety of bevacizumab administration in patients older than 65 years.

Methods: We have retrospectively analyzed the archive data of 65 patients with epithelial ovarian, fallopian tube, or primary peritoneal cancer who started treatment with bevacizumab in primary advanced and in first relapse setting at the Department of Gynecologic Oncology in the University Hospital Centre Zagreb in the period from January 2017 to December 2018. Patients were divided in two categories according to age: group 1 ( $\leq 65$ years) and group 2 (>65 years).

Results: Our analysis included 65 patients:47 (72.3\%) patients in group 1 compared with 18 (27.7\%) in group 2. Bevacizumab was administered to $39(60 \%)$ patients as first-line treatment and to $26(40 \%)$ patients as second-line treatment. The median age was 70 years (range 66-76 years) in group 2 and 55 years (range 35-65 years) in group 1. ECOG status 0 had $44.7 \%$ of patients in group 1 compared with only $22 \%$ in group 2 . At the time of diagnosis, elderly patients had presented with at least one comorbidity in $94.4 \%$ of the cases, compared with $42.6 \%$ in group 1 . The median number of cycles of bevacizumab was 9 in elderly patients and 17 cycles in group 1. Among those patients receiving bevacizumab in the first-line setting, median progression free interval (PFI) was 12 months in younger patients versus 7 months in elderly patients. Similarly, among those receiving bevacizumab in the second-line setting PFI was 9 months in younger patients versus 1 months in elderly patients. The occurrence of non-hematological adverse events did not increase in elderly patients; $51.1 \%$ of patients in group 1 reported some of non-hematological adverse events versus only $27.8 \%$ in elderly patients.

Conclusion: Our experience in treating patients with bevacizumab shows good results with acceptable toxicity and our findings suggest that its use in the elderly population should be considered as safe and manageable.

KEYWORDS: ovary cancer, bevacizumab, therapy, elderly patients

\section{INTRODUCTION}

In recent years, ovarian cancer (OC) became the most lethal gynecologic malignancy. According to global estimates 295,414 new cases were detected in
Corresponding author: Kristina Katić, Department of Gynecologic Oncology, Clinical Department of Gynecology and Obstetrics, University Hospital Centre Zagreb, Petrova 13, 10000 Zagreb, Croatia. e-mail: kristina.katic@kbc-zagreb.hr 
2018, and 184,799 people were died from the disease (1). In Croatia, it is the seventh most common cancer among women. The estimated number of new ovarian cancer cases in Croatia in 2017 was 449 with 330 deaths (2). The lack of characteristic symptoms and effective screening tests for early detection of ovarian cancer has led to delayed diagnosis and poor prognosis. The standard treatment of our patients is cytoreductive surgery followed by platinum-based chemotherapy $(3,4)$. Standard chemotherapy consists of combination of paclitaxel $175 \mathrm{mg} / \mathrm{m}^{2}$ and carboplatin AUC 5-6, both administered intravenously, every 3 weeks. In patients with a disseminated disease, one option is neoadjuvant chemotherapy with interval debulking surgery after three to four cycles of chemotherapy $(3,4,5,6)$.

Various attempts had been made to improve systemic treatments for ovarian cancer. The two most promising molecular targeting class of agents are anti-angiogenic agents and poly-ADP ribose polymerase inhibitors.

Bevacizumab is a monoclonal antibody that targets vascular endothelial growth factor. It is used in the treatment of many cancers. Bevacizumab is the first targeted therapy approved by the European Medicines Agency (EMA) for the treatment of the advanced and metastatic ovarian cancer, fallopian tube, or primary peritoneal cancer stage III or IV in combination with three-weekly carboplatin and paclitaxel in the first line therapy. It is approved due to the results of two randomized controlled phase III trials: GOG-0218 and ICON-7 study $(7,8)$. These both studies demonstrated an improvement of progression-free survival (PFS), especially in the high-risk ovarian cancer population. In the ICON7 trial, a survival benefit was observed in an exploratory analysis of a high-risk subgroup (FIGO IIIB and IIIC stage with residual disease after surgery and patients with FIGO IV stage) and in the GOG-0218 trial a survival benefit was observed only in patients with FIGO stage IV $(9,10)$. Bevacizumab is approved for first relapse of the disease regardless of the time elapsed since previous platinum based chemotherapy. Two trials phase III: OCEANS and GOG-0213 $(11,12,13)$ showed that bevacizumab during chemotherapy (with gemcitabine/carboplatin or paclitaxel/carboplatin) and as maintenance therapy improved of PFI in patients with platinum-sensitive ovarian cancer. Bevacizumab is also approved in patients with platinum resistant ovarian cancer according AURELIA phase III trial (14). The effectiveness of chemotherapy with bevacizumab in patients with platinum-resistant ovarian cancer is confirmed in REBECA trial (15).

The incidence of ovarian cancer increases with age. Approximately $50 \%$ of patients with ovarian cancer are older than 65 years (16). The population tend to be aging and that is reason why the number of older patients with ovarian cancer will be increase. Despite the high prevalence of the ovarian cancer in elderly and the fact that increased age is a negative prognostic factor, the management of these patients is often less aggressive than in younger patients. There are several reasons for that: expectation of worse tolerability of therapy because of comorbidities and poor performance status due to Eastern Cooperative Oncology Group (ECOG) and sometimes some older patients decline therapy that is more intensive because they choose a better quality of life over the duration. Despite that, most studies and analyses have shown that older patients can tolerate chemotherapy and molecular targeting agents at similar dose intensity as younger patients without a significant impact on quality of life (QoL) and increased survival $(17,18)$. Undertreatment may contribute the shorter survival expectations in older patients $(19,20)$. Many trials did not have include many older people in trial because of strict inclusion criteria. Therefore, it is important to understand whether toxicity has increased in older patients.

Our aim was to investigate the safety of bevacizumab administration in patients older than 65 years.

\section{METHODS}

In a retrospective study, we have analyzed the medical data of 65 patients with newly diagnosed advanced FIGO IIIB-IV or recurrent epithelial ovarian, fallopian tube, or primary peritoneal cancer who received bevacizumab during their treatment and who were treated at the Department of Gynecology and Obstetrics in the University Hospital Centre Zagreb in the period from January 2017 to December 2018. As first line chemotherapy we administered three-weekly paclitaxel $\left(175 \mathrm{mg} / \mathrm{m}^{2}\right)$ and carboplatin (area under 
Lib Oncol. 2021;49(1):10-19

Table1.

Characteristics of the patients

\begin{tabular}{|c|c|c|c|c|}
\hline \multirow{2}{*}{\multicolumn{2}{|c|}{$\begin{array}{l}\text { Characterictics } \\
(\mathrm{N}=65)\end{array}$}} & All cases & $\begin{array}{c}\text { Group } 1 \\
(\leq 65 \text { years })\end{array}$ & $\begin{array}{c}\text { Group } 2 \\
(>65 \text { years })\end{array}$ \\
\hline & & $\mathrm{N}(\%)$ & $\mathrm{N}(\%)$ & $\mathrm{N}(\%)$ \\
\hline \multicolumn{2}{|c|}{$\begin{array}{l}\text { Age, median } \\
\text { (years) }\end{array}$} & 60 & 55 & 70 \\
\hline \multicolumn{2}{|c|}{$\begin{array}{l}\text { Age, range } \\
\text { (years) }\end{array}$} & $35-76$ & $35-65$ & $66-76$ \\
\hline \multicolumn{5}{|c|}{ ECOG PS } \\
\hline \multicolumn{2}{|r|}{0} & $25(38 \%)$ & $21(45 \%)$ & $4(22 \%)$ \\
\hline \multicolumn{2}{|r|}{1} & $40(62 \%)$ & $26(55 \%)$ & $14(78 \%)$ \\
\hline \multicolumn{2}{|c|}{$\begin{array}{l}\text { Comorbidities } \\
\text { (number) }\end{array}$} & & & \\
\hline & 0 & $21(32 \%)$ & $20(42 \%)$ & $1(5 \%)$ \\
\hline \multicolumn{2}{|r|}{1} & $17(26 \%)$ & $14(30 \%)$ & $3(17 \%)$ \\
\hline & 2 & $14(22 \%)$ & $9(19 \%)$ & $5(28 \%)$ \\
\hline \multicolumn{2}{|r|}{$\geq 3$} & $13(20 \%)$ & $4(9 \%)$ & $9(50 \%)$ \\
\hline \multicolumn{5}{|c|}{$\begin{array}{l}\text { Comorbidities } \\
\text { type* }\end{array}$} \\
\hline & Hypertension & $39(60 \%)$ & $24(51 \%)$ & $15(83 \%)$ \\
\hline & Diabetes & $4(6 \%)$ & $2(4 \%)$ & $2(11 \%)$ \\
\hline & Obesity & $8(12 \%)$ & $5(11 \%)$ & $3(17 \%)$ \\
\hline & CV diseases & $9(14 \%)$ & $3(6 \%)$ & $6(33 \%)$ \\
\hline & GI diseases & $6(9 \%)$ & $3(6 \%)$ & $3(17 \%)$ \\
\hline & Pulmonary & $3(5 \%)$ & $1(2 \%)$ & $2(11 \%)$ \\
\hline & Arthritis & $2(3 \%)$ & 0 & $2(11 \%)$ \\
\hline & Other cancer & $3(5 \%)$ & $3(6 \%)$ & 0 \\
\hline & Other disease & $11(17 \%)$ & $5(11 \%)$ & $6(33 \%)$ \\
\hline \multicolumn{5}{|c|}{\begin{tabular}{|l} 
Primary \\
tumor site
\end{tabular}} \\
\hline & Ovary & $51(78 \%)$ & $41(88 \%)$ & $10(56 \%)$ \\
\hline & Fallopian tube & $7(11 \%)$ & $3(6 \%)$ & $4(22 \%)$ \\
\hline & Peritoneum & $7(11 \%)$ & $3(6 \%)$ & $4(22 \%)$ \\
\hline \multicolumn{5}{|c|}{$\begin{array}{l}\text { FIGO stage } \\
\text { of disease }\end{array}$} \\
\hline & Stages I-II & $1(2 \%)$ & $1(2 \%)$ & 0 \\
\hline & Stage III & $47(72 \%)$ & $35(75 \%)$ & $12(67 \%)$ \\
\hline & IIIA & $2(3 \%)$ & $2(4 \%)$ & 0 \\
\hline & IIIB & $6(9 \%)$ & $3(6 \%)$ & $3(17 \%)$ \\
\hline & IIIC & $39(60 \%)$ & $30(65 \%)$ & $9(50 \%)$ \\
\hline & Stage IV & $17(26 \%)$ & $11(23 \%)$ & $6(33 \%)$ \\
\hline & IVA & $6(9 \%)$ & $3(6 \%)$ & $3(16.5 \%)$ \\
\hline & IVB & $11(17 \%)$ & $8(17 \%)$ & $3(16.5 \%)$ \\
\hline
\end{tabular}

\begin{tabular}{|c|c|c|c|}
\hline \multirow{2}{*}{$\begin{array}{l}\text { Characterictics } \\
(\mathrm{N}=65)\end{array}$} & All cases & $\begin{array}{c}\text { Group } 1 \\
\text { ( } \leq 65 \text { years) }\end{array}$ & $\begin{array}{c}\text { Group } 2 \\
(>65 \text { years })\end{array}$ \\
\hline & $\mathrm{N}(\%)$ & $N(\%)$ & $N(\%)$ \\
\hline \multicolumn{4}{|l|}{$\begin{array}{l}\text { Patohistological type } \\
\text { of tumor }\end{array}$} \\
\hline \begin{tabular}{|l} 
Serous \\
carcinoma
\end{tabular} & $58(88 \%)$ & $40(85 \%)$ & $18(100 \%)$ \\
\hline $\begin{array}{l}\text { Endometrioid } \\
\text { Carcinoma }\end{array}$ & $3(5 \%)$ & $3(6 \%)$ & 0 \\
\hline $\begin{array}{l}\text { Mucinous } \\
\text { carcinoma }\end{array}$ & $1(2 \%)$ & $1(2 \%)$ & 0 \\
\hline $\begin{array}{l}\text { Clear cell } \\
\text { carcinoma }\end{array}$ & $1(2 \%)$ & $1(2 \%)$ & 0 \\
\hline $\begin{array}{l}\text { Borderline } \\
\text { carcinoma }\end{array}$ & $2(3 \%)$ & $2(4 \%)$ & 0 \\
\hline \multicolumn{4}{|l|}{ Tumor grade } \\
\hline Low grade & $7(11 \%)$ & $7(15 \%)$ & $\mathrm{O}$ \\
\hline High grade & $58(89 \%)$ & $40(85 \%)$ & $18(100 \%)$ \\
\hline \multicolumn{4}{|l|}{ BRCA mutation } \\
\hline BRCA1 positive & $8(12 \%)$ & $8(17 \%)$ & 0 \\
\hline BRCA2 positive & $1(2 \%)$ & $1(2 \%)$ & 0 \\
\hline BRCA wild type & $56(86 \%)$ & $38(81 \%)$ & $18(100 \%)$ \\
\hline \multicolumn{4}{|l|}{$\begin{array}{l}\text { Surgical approach at } \\
\text { primary surgery }\end{array}$} \\
\hline PDS & $51(78 \%)$ & $37(79 \%)$ & $14(78 \%)$ \\
\hline NACT+IDS & $14(22 \%)$ & $10(21 \%)$ & $4(22 \%)$ \\
\hline \multicolumn{4}{|l|}{$\begin{array}{l}\text { Chemotherapy } \\
\text { regimen }\end{array}$} \\
\hline PC-BEV ( $1^{\text {st }}$ line $)$ & $39(60 \%)$ & $29(62 \%)$ & $11(61 \%)$ \\
\hline $\begin{array}{l}\text { GC-BEV }\left(2^{\text {nd }}\right. \\
\text { line })\end{array}$ & $17(27 \%)$ & $12(26 \%)$ & $5(28 \%)$ \\
\hline $\begin{array}{l}\text { PC-BEV }\left(2^{\text {nd }}\right. \\
\text { line })\end{array}$ & $3(5 \%)$ & $3(6 \%)$ & 0 \\
\hline $\begin{array}{l}\text { TOPO-BEV }\left(2^{\text {nd }}\right. \\
\text { line })\end{array}$ & $1(2 \%)$ & $1(2 \%)$ & 0 \\
\hline $\begin{array}{l}\text { wPAC-BEV }\left(2^{\text {nd }}\right. \\
\text { line })\end{array}$ & $4(6 \%)$ & $2(4 \%)$ & $2(11 \%)$ \\
\hline
\end{tabular}

* Some patients have more than one comorbidity

ECOG PS = Eastern Cooperative Oncology Group performance status; FIGO = International Federation of Gynecology and Obstetrics; CV diseases = cardiovascular diseases; GI diseases = gastrointestinal diseases; PDS = primary debulking surgery; NACT+IDS = neoadjuvant chemotherapy followed by interval debulking surgery; $\mathrm{BEV}=$ Bevacizumab; $\mathrm{PC}=$ paclitaxel/ carboplatin (three-weekly); GC = gemcitabine/carboplatin; TOPO = topotecan; wPAC = weekly paclitaxel

curve (AUC) 5-6). Bevacizumab (15 mg/kg) is administrated during chemotherapy and as maintenance therapy as a single agent, for a total of up to 22 cycles. As second-line chemotherapy, in patients with platinum sensitive ovarian cancer is administrated carboplatin (AUC4) plus gem-

citabine $1000 \mathrm{mg} / \mathrm{m}^{2}$ or carboplatin (AUC 5-6) plus paclitaxel $175 \mathrm{mg} / \mathrm{m}^{2}$ and bevacizumab $(15 \mathrm{mg} / \mathrm{kg})$ followed by bevacizumab maintenance therapy until disease progression. In patients with platinum resistant $\mathrm{OC}$, as second-line is administrated weekly paclitaxel $\left(80 \mathrm{mg} / \mathrm{m}^{2}\right)$ or topotecan $(1.5$ 


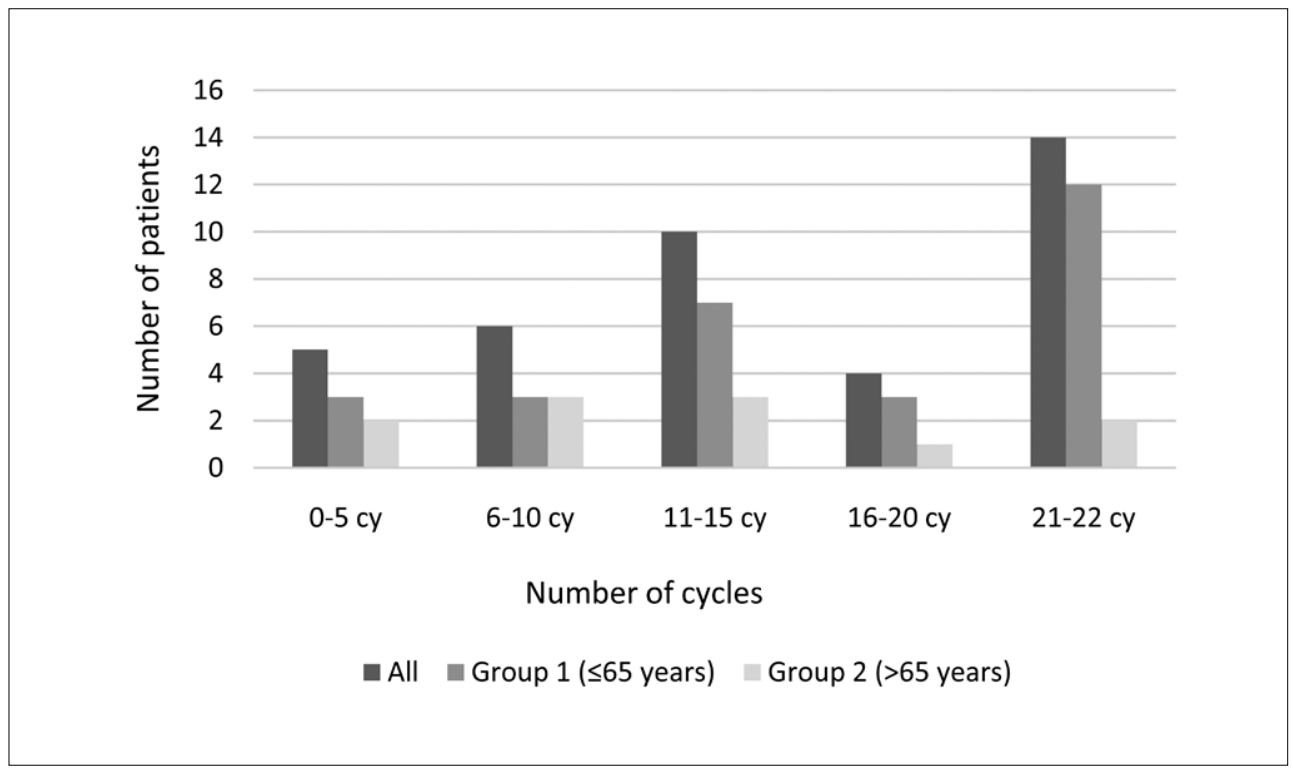

Figure 1. Summary of treatment exposure to bevacizumab in the first-line setting

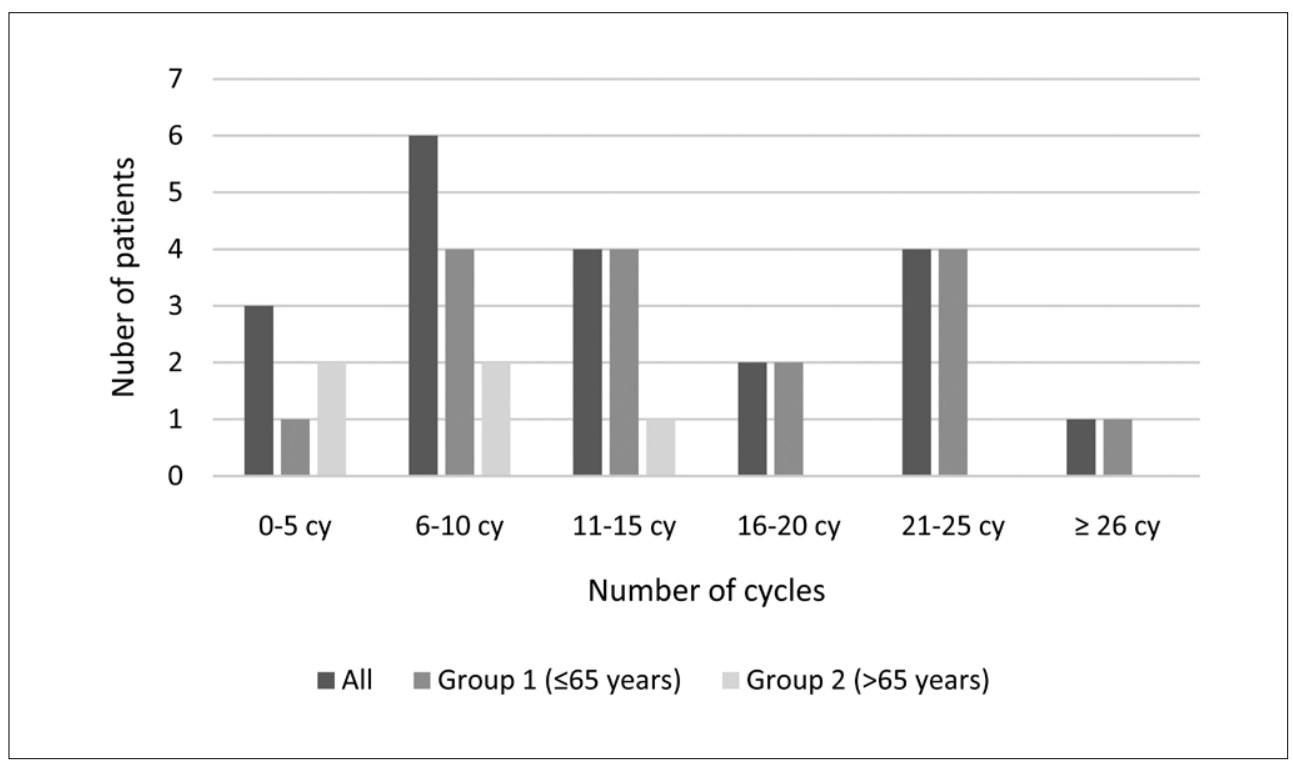

Figure 2. Summary of treatment exposure to bevacizumab in patients with platinum sensitive ovarian cancer in the second-line setting

$\mathrm{mg} / \mathrm{m}^{2}$ during 5 days every three week) and bevacizumab (15 mg/kg 3-weekly) followed by bevacizumab maintenance therapy until disease progression.

Patients are divided in two categories according to age: group 1 ( $\leq 65$ years) and group 2 (>65 years). We have analyzed the data: age, ECOG sta- tus, stage of disease, comorbidities, principle of surgery (primary surgery or interval debulking surgery), pathohistological type of the tumor, number and type of adjuvant chemotherapy, number of bevacizumab cycles, side effects related to bevacizumab application. Patients were followed up until March 2020. Quantitative variables 


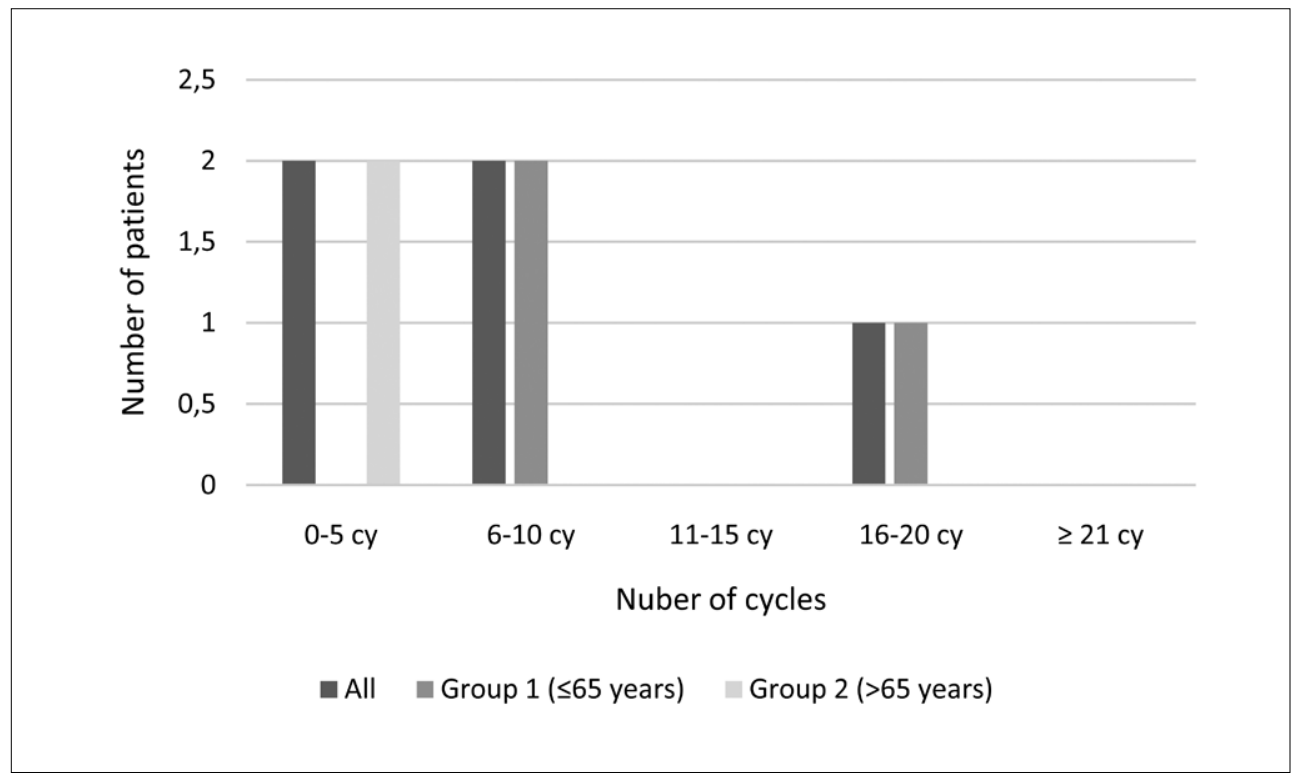

Figure 3. Summary of treatment exposure to bevacizumab in patients with platinum resistant ovarian cancer in the second-line setting

Table 2.

Adverse events (CTCAE v5.0) among patients and according to age

\begin{tabular}{|c|c|c|c|c|c|c|c|}
\hline \multirow[t]{2}{*}{ Adverse events* } & \multirow{2}{*}{$\begin{array}{c}\text { Number } \\
\text { of all patients } \\
\text { (percentage) }\end{array}$} & \multicolumn{3}{|c|}{$\begin{array}{l}\text { Number of patients in group } 1 \\
\text { (percentage) }\end{array}$} & \multicolumn{3}{|c|}{$\begin{array}{c}\text { Number of patients in group } 2 \\
\text { (percentage) }\end{array}$} \\
\hline & & All AEs & G1/G2 AEs & G3/G4 AEs & All AEs & G1/G2 AEs & G3/G4 AEs \\
\hline Hypertension & $10(25 \%)$ & $8(17 \%)$ & $6(13 \%)$ & $2(4 \%)$ & $2(13 \%)$ & $1(6.5 \%)$ & $1(6.5 \%)$ \\
\hline Venous thromboembolic events & $4(6 \%)$ & $2(4 \%)$ & $2(4 \%)$ & 0 & $2(13 \%)$ & $1(6.5 \%)$ & $1(6.5 \%)$ \\
\hline llues & $3(5 \%)$ & $3(6 \%)$ & $1(2 \%)$ & $2(4 \%)$ & 0 & 0 & 0 \\
\hline Proteinuria & $9(14 \%)$ & $8(17 \%)$ & $8(17 \%)$ & 0 & $1(6.5 \%)$ & $1(6.5 \%)$ & 0 \\
\hline Vesicovaginal fistula & $1(2 \%)$ & $1(2 \%)$ & 0 & $1(2 \%)$ & 0 & 0 & 0 \\
\hline Headache & $3(5 \%)$ & $3(6 \%)$ & $2(4 \%)$ & $1(2 \%)$ & 0 & 0 & 0 \\
\hline Tachycardia & $1(2 \%)$ & $1(2 \%)$ & $1(2 \%)$ & 0 & 0 & 0 & 0 \\
\hline Bleeding & $2(3 \%)$ & $2(4 \%)$ & $2(4 \%)$ & 0 & 0 & 0 & 0 \\
\hline Creatinine increase & $2(3 \%)$ & $1(2 \%)$ & $1(2 \%)$ & 0 & $1(6.5 \%)$ & $1(6.5 \%)$ & 0 \\
\hline
\end{tabular}

*Some patients experienced more than one adverse event

CTCEA v.5.0= Common Terminology Criteria for Adverse Events version 5.0; $A E s=$ adverse events; $\mathrm{G}=$ grade

were expressed as mean and median values. Qualitative variables are expressed as absolute and relative frequencies.

\section{RESULTS}

Our analysis included 65 patients: $47(72.3 \%)$ patients in group 1 compared with 18 (27.3\%) in group 2. The number of included patients in group
1 were lower because the total number of treated patients older than 65 years was lower than those $\leq 65$ years, and some of the elderly patients were un-fit for bevacizumab therapy (they had more comorbidities and poor ECOG status). Bevacizumab has been administered to $39(60 \%)$ patients as firstline treatment and to 26 (40\%) patients as secondline treatment. The median age was 55 years (range 35-65 years) in group 1 and 70 years (range 
Lib Oncol. 2021;49(1):10-19

Table 3.

Bevacizumab in first-line setting

\begin{tabular}{|c|c|c|c|c|c|c|c|}
\hline \multirow[b]{2}{*}{ Study } & \multirow[b]{2}{*}{ Phase } & \multirow[b]{2}{*}{ Patients } & \multirow[b]{2}{*}{ Treatment } & \multicolumn{2}{|l|}{ All patients } & \multicolumn{2}{|c|}{ High-risk patients } \\
\hline & & & & $\begin{array}{l}\text { Median PFS } \\
\text { (months) }\end{array}$ & $\begin{array}{l}\text { Median OS } \\
\text { (months) }\end{array}$ & \begin{tabular}{|l|} 
Median \\
PFS \\
(months)
\end{tabular} & $\begin{array}{l}\text { Median OS } \\
\text { (months) }\end{array}$ \\
\hline \multirow{3}{*}{$\begin{array}{l}\text { GOG-0218 } \\
\text { Burger et al. (7) } \\
\text { Tewari et al. (10) }\end{array}$} & \multirow{3}{*}{ III } & \multirow{3}{*}{$\begin{array}{l}\text { FIGO stage III-IV } \\
(n=1873)\end{array}$} & $\begin{array}{l}\text { Carboplatin + paclitaxel } \\
+ \text { placebo }\end{array}$ & 10.3 & 41.1 & NA & $\begin{array}{l}32.6 \\
\text { (for FIGO } \\
\text { stage IV) }\end{array}$ \\
\hline & & & $\begin{array}{l}\text { Carboplatin + paclitaxel } \\
+ \text { bevacizumab } 15 \mathrm{mg} / \mathrm{kg} \\
\text { from cycle } 2 \text { through } 6\end{array}$ & 11.2 & 40.8 & NA & $\begin{array}{l}34.5 \\
\text { (for FIGO } \\
\text { stage IV) }\end{array}$ \\
\hline & & & $\begin{array}{l}\text { Carboplatin + paclitaxel } \\
\text { + bevacizumab } 15 \mathrm{mg} / \mathrm{kg} \\
\text { from cycle } 2 \text { through } 22 \\
\text { for } 15 \text { months }\end{array}$ & 14.1 & 43.4 & NA & $\begin{array}{l}42.8 \\
\text { (for FIGO } \\
\text { stage IV) }\end{array}$ \\
\hline \multirow{2}{*}{$\begin{array}{l}\text { ICON-7 } \\
\text { Perren et al. (8) } \\
\text { Oza et al. (9) }\end{array}$} & \multirow[b]{2}{*}{ III } & \multirow{2}{*}{$\begin{array}{l}\text { FIGO stage I-II grade } \\
3 \text { or clear cell subtype } \\
\text { or FIGO stage IIB-IV } \\
(n=1528)\end{array}$} & Carboplatin + paclitaxel & 17.4 & 44.6 & 10.5 & 34.5 \\
\hline & & & $\begin{array}{l}\text { Carboplatin + paclitaxel } \\
+ \text { bevacizumab } 7.5 \mathrm{mg} / \mathrm{kg} \\
\text { for } 12 \text { months }\end{array}$ & 19.8 & 45.5 & 15.9 & 39.3 \\
\hline
\end{tabular}

FIGO= International Federation of Gynecology and Obstetrics; NA= not available; PFS= progression free survival; OS= overall survival

Table 4.

Bevacizumab in second-line setting

\begin{tabular}{|c|c|c|c|c|c|c|c|}
\hline Study & Phase & Patients & Treatment & $\begin{array}{l}\text { Median PFS } \\
\text { (months) }\end{array}$ & $\mathrm{HR}$ & $\begin{array}{l}\text { Median OS } \\
\text { (months) }\end{array}$ & HR \\
\hline \multirow{2}{*}{$\begin{array}{l}\text { OCEANS } \\
\text { Aghajanian et al. } \\
(11,13)\end{array}$} & \multirow[b]{2}{*}{ III } & \multirow{2}{*}{$\begin{array}{l}\text { Platinum sensitive } \\
\text { recurrent OC } \\
(n=484)\end{array}$} & Carboplatin + gemcitabine & 8.4 & \multirow[b]{2}{*}{0.84} & 32.9 & \multirow[b]{2}{*}{0.95} \\
\hline & & & $\begin{array}{l}\text { Carboplatin + gemcitabine } \\
\text { + bevacizumab }\end{array}$ & 12.4 & & 33.6 & \\
\hline \multirow{2}{*}{$\begin{array}{l}\text { GOG-213 } \\
\text { Coleman et al. } \\
(12)\end{array}$} & \multirow[b]{2}{*}{ III } & \multirow{2}{*}{$\begin{array}{l}\text { Platinum sensitive } \\
\text { recurrent OC } \\
(n=674)\end{array}$} & Carboplatin + paclitaxel & 10.4 & \multirow[b]{2}{*}{0.61} & 37.3 & \multirow[b]{2}{*}{0.82} \\
\hline & & & $\begin{array}{l}\text { Carboplatin + paclitaxel } \\
+ \text { bevacizumab }\end{array}$ & 13.8 & & 42.2 & \\
\hline \multirow{2}{*}{$\begin{array}{l}\text { AURELIA } \\
\text { Pujade-Lauraine et al. } \\
(14)\end{array}$} & \multirow{2}{*}{ III } & \multirow{2}{*}{$\begin{array}{l}\text { Platinum resistant } \\
\text { recurrent OC } \\
(n=361)\end{array}$} & $\begin{array}{l}\text { Chemotherapy } \\
\text { (weekly paclitaxel, } \\
\text { PLD or topotecan) }\end{array}$ & 3.4 & \multirow{2}{*}{0.42} & 13.3 & \multirow{2}{*}{0.85} \\
\hline & & & \begin{tabular}{|l|} 
Chemotherapy \\
(weekly paclitaxel, PLD \\
or topotecan) + bevacizumab
\end{tabular} & 6.7 & & 16.6 & \\
\hline
\end{tabular}

$\mathrm{OC}=$ ovarian cancer, $\mathrm{PFS}=$ progression free survival; $\mathrm{OS}=$ overall survival; $\mathrm{HR}=$ hazard ratio; $\mathrm{PLD}=$ pegylated liposomal doxorubicin

66-76 years) in group 2. ECOG status 0 had $44.7 \%$ of patients in group 1 compared with only $22 \%$ in group 2 . The primary tumor site in the most patients were ovary $(78 \%)$. The majority of patients presented with FIGO stage IIIC at diagnosis (39 patients- $61 \%$ ) and with serous subtype (89\%). Stage distribution were similar among older and younger patients. All patients in group 2 had serous type of cancer as the most patients in group 1 , but small percentage in group 1 had also different subtypes of cancer. At the time of diagnosis, elder- ly patients had presented with at least one comorbidity in $94.4 \%$ of the cases, compared with $42.6 \%$ in group 1 . The most common comorbidity was hypertension in both groups (Table1).

The majority of patients $(60 \%)$ received bevacizumab in the first-line setting, with three-weekly paclitaxel/carboplatin chemotherapy followed as maintenance therapy. In all patients, the median number of cycles of bevacizumab was 9 in elderly patients and 17 cycles in group 1 . In the first-line setting, the median number of applicated cycles of 
bevacizumab was 18 cycles in group 1 and $11 \mathrm{cy}-$ cles in group 2 (Figure 1.) In patients with platinum sensitive OC who received bevacizumab in the second-line therapy, the median number of applicated cycles of bevacizumab was 13 in group 1 and 7 cycles in group 2 (figure 2.). Similarly, in patients with platinum resistant $\mathrm{OC}$, the median number of bevacizumab's cycles was 9 in group 1 and 3 in elderly patients (Figure 3 ).

Among those patients receiving bevacizum$\mathrm{ab}$ in the first-line setting, median progression free interval (PFI) was 12 months in younger patients versus 7 months in elderly patients. Similarly, among those receiving bevacizumab in the second-line setting PFI was 9 months in younger patients versus 1 months in elderly patients. The occurrence of non-hematological adverse events did not increase in elderly patients; $51.1 \%$ of patients in group 1 reported some of non-hematological adverse events versus only $27.8 \%$ in elderly patients. The most common adverse event in both groups was hypertension (table 2 .)

\section{DISCUSSION}

In Croatia, bevacizumab has been established in the treatment of ovarian cancer since 2017. In first line setting, we have opportunity to treat patients with bevacizumab if it is found locally advanced disease (FIGO stage IIIB or IIIC) with residual disease after surgery and in metastatic disease (FIGO stage IV) according to results from GOG-0218 and ICON7 trials $(7,8,9,10)$. Details of the studies about first-line setting are summarized in table 3 . In second- line setting, we can treat patients with bevacizumab regardless off time elapsed since the first line chemotherapy according to results from OCEANS and AURELIA trials $(11,13,14)$. The characteristics of the studies are summarized in table 4 .

Overall, bevacizumab is generally well tolerated. Its toxicities are not usually overlapping with those of cytotoxic chemotherapy, but may add to the adverse events commonly seen with chemotherapy. The majority of adverse events are mild in severity and manageable, but some do result in significant morbidity. Many adverse events associated with bevacizumab were observed during clinical trials like hypertension, proteinuria, thromboembolism, gastrointestinal events, wound healing complications and others $(7,8,11,12,14,15,17)$. Liang in his meta-analysis showed that the use of angiogenesis inhibitors was associated with a statistically increased risk in four of the adverse outcomes studied: arterial thromboembolic events, gastrointestinal perforation, proteinuria, and hypertension (21). Hypertension was the most common adverse event associated with bevacizumab treatment. Hypertension occurred in 12 to $41 \%$ of patients with bevacizumab and it occurred more frequently in the frontline bevacizumab treatment group than in the recurrence treatment group $(7,8,11,14,22)$.

The elderly patients are often undertreated. The study from the FRANCOGYN group demonstrated that $77 \%$ of the younger women received optimal treatment compared with $51 \%$ of the older women. The older women. They demonstrated that patients older than 75 years had less aggressive surgery procedure, and that they received more chemotherapy with carboplatin only and less bevacizumab (23). A recent French study (EWOC-1 trial) showed that in elderly patients with ovarian cancer, carboplatin monotherapy or weekly carboplatin plus paclitaxel are often proposed as an alternative to three-weekly carboplatin/paclitaxel, but they showed that compared to the three-weekly and weekly carboplatin plus paclitaxel regimens, the carboplatin single agent was reported to be less active with a significantly worse survival outcome in vulnerable elderly patients, and carboplatin/paclitaxel remains a standard of treatment (24). Therefore, undertreatment contributed to shorter survival in elderly patients. In order to avoid exclusion of older patients from bevacizumab therapy, it is important to investigate tolerability and safety of bevacizumab in those patients.

In our study, we evaluated tolerability of bevacizumab therapy in older patients with ovarian cancer. Our findings suggest that older patients with ovarian cancer generally tolerated bevacizumab therapy as well as younger patients. In our study, the patients aged $>65$ years did not have more adverse events than younger one.

Data about use of bevacizumab in elderly patients in first-line settings are available from the ROSIA, OTILIA and TURBO trials. All three trials agree that bevacizumab can be safely considered in the frontline treatment irrespective of age $(17,25,26)$. The ROSIA trial evaluated the safety 
and efficacy of extending bevacizumab therapy beyond 15 months in non-progressive ovarian cancer patients. That trial demonstrated that in bevacizumab-treated ovarian cancer patients aged $\geq 70$ years, the incidences of low-grade diarrhea and grade $\geq 3$ hypertension, thromboembolic events, and asthenia were higher than those in patients aged $<70$ years. Median PFS was similar in both groups despite worse prognosis in older patients. The conclusion of this study was that older age should not preclude use of bevacizumab for ovarian cancer in carefully selected patients aged $\geq 70$ years. (17). The TURBO trial suggests that age per se is not a predictive factor of adverse events for patients receiving bevacizumab. They suggest that predictive factors for increased toxicity are higher creatinine serum level $(>1.1 \mathrm{~g} / \mathrm{dl})$, estimated glomerular filtration rate (eGFR) $\leq 60 \mathrm{ml} / \mathrm{min}$ and $\geq 3$ comorbidities (26).

There are several trials which evaluated use of bevacizumab in elderly patients with recurrent ovarian cancer $(26,27,28)$. Subgroup analysis of the AURELIA trial demonstrated that older patients aged $\geq 65$ years experienced more often hypertension grade $\geq 3$ with similar improvements in response rates. There was no excess of other adverse events of specific interest for bevacizumab in older women.

Beinse in his trial demonstrated that older women aged $\geq 70$ years experienced more often hypertension grade $\geq 3$ if they had baseline hypertension but not in patients without baseline hypertension. In his trial, other adverse events were similar in both groups (28).

Our findings suggest that older patients aged $>65$ years with ovarian cancer did not have more adverse events than younger patients and perhaps the reason for that is lower number of applicated cycles of bevacizumab in older patients. In most patients, the main reason for bevacizumab interruption was disease progression, not toxicity. Hence, bevacizumab is an active and tolerable front-line treatment option that should be considered irrespective of age.

\section{CONCLUSION}

In Croatia, from February 2017 we have opportunity to treat patients with epithelial ovarian, fallopian tube, or primary peritoneal cancer with bevacizumab in the first-line and second-line settings. Our experience in treating patients with bevacizumab shows good results with acceptable toxicity and our findings suggest that its use in the elderly population should be considered as safe and manageable.

\section{REFERENCES}

1. Bray F, Ferlay J, Soerjomataram I, et al. Global cancer statistics 2018: GLOBOCAN estimates of incidence and mortality worldwide for 36 cancers in 185 countries. CA: A Cancer J Clin. 2018; 68(6):394-424.

2. https://www.hzjz.hr/wp-content/uploads/2017/01/ Bilten-2017-final.pdf

3. Colombo N, Sessa C, du Bois A, et al. ESMO-ESGO consensus conference recommendations on ovarian cancer: pathology and molecular biology, early and advanced stages, borderline tumors and recurrent disease. Annals of Oncology 2019; 30: 672-705.

4. https://www.ncen.org

5. Makar AP, Tropé CG, Tummers P, Denys H, Vandecasteele K. Advanced Ovarian Cancer: Primary or Interval Debulking? Five Categories of Patients in View of the Results of Randomized Trials and Tumor Biology: Primary Debulking Surgery and Interval Debulking Surgery for Advanced Ovarian Cancer. Oncologist. 2016; 21(6):745-754.

6. Wright AA, BohlkeK, Armstrong DK et al., Neoadjuvant chemotherapy for newly diagnosed, advanced ovarian cancer: Society of Gynecologic Oncology and American Society of Clinical Oncology Clinical Practice Guideline, J Clin Oncol 2016; 1;34 (28):3460-73.

7. Burger RA, Brady MF, Bookman MA, et al. Gynecologic Oncology Group Incorporation of bevacizumab in the primary treatment of ovarian cancer. N Engl J Med. 2011; 365(26):2473-2483.

8. Perren TJ, Swart AM, Pfisterer J, et al. A phase 3 trial of bevacizumab in ovarian cancer. N Engl J Med. 2011; 365(26):2484-2496.

9. Oza AM, Cook AD, Pfisterer J, et al. Standard chemotherapy eith or without bevacizumab for women with newly diagnosed ovarian cancer (ICON7): Overall survival results of phase 3 randomised trial. Lancet Oncol 2015; 16:928-936

10. Tewari KS, Burger RA, Enserro D, et al. Final Overall Survival of a Randomised Trial of bevacizumab for Primary Treatment of Ovarian Cancer. J Clin Oncol 2019; 37(26):2317-2318.

11. Aghajanian C, Blank SV, Goff BA, et al.: OCEANS: A randomized, double-blind, placebo-controlled phase III trial of chemotherapy with or without bevacizum$\mathrm{ab}$ in patients with platinum-sensitive recurrent epithelial ovarian, primary peritoneal, or fallopian tube cancer. J Clin Oncol 2012;30: 2039- 2045. 
12. Coleman RT, Brady MF, Herzog TJ, et al.: Bevacizum$\mathrm{ab}$ and paclitaxel-carboplatin chemotherapy and secondary cytoreduction in recurrent, platinum-sensitive ovarian cancer (NRG Oncology/Gynecologic Oncology Group study GOG-0213): a multicentre, open-label, randomised, phase-3; The Lancet Oncol 2017;18(6): 779-791.

13. Aghajanian C, Goff B, Nycum LR, et al.: Final overall survival and safety analysis of OCEANS, a phase 3 trial of chemotherapy with or without bevacizumab in patients with platinum-sensitive recurrent ovarian cancer. Gynecol Oncol. 2015;139(1):10-16.

14. Pujade-Lauraine E, Hilpert F, Weber B, et al.: Bevacizumab combined with chemotherapy for platinumresistant recurrent ovarian cancer: The AURELIA open-label randomized phase III trial. J Clin Oncol. 2014;1;32(13):1302-1308.

15. Lee JL, Park JY, Park SY, et al: Real-world effectiveness of bevacizumab based on AURELIA in platinum-resistant recurrent ovarian cancer (REBECA): A Korean Gynecologic Oncology Group study (KGOG 3041). Gynecol Oncol. 2019;152(1):61-67.

16. Siegel RL, Miller KD and Jamal A: Cancer statistics, 2019. CA Cancer J Clin 69(1):7-34.

17. Selle F, Colombo N, Korach J, Mendiola C, Cardona A, Ghazi $\mathrm{Y}$, et al. Safety and efficacy of extended bevacizumab therapy in elderly ( $\geq 70$ Years) versus younger patients treated for newly diagnosed ovarian cancer in the international ROSiA study. Int J Gynecol Cancer. 2018;28:729-737.

18. Trosso-Sandova TA, Lichtman SM: Chemotherapy of ovarian cancer in elderly patients. Cancer Biol Med. 2015;21(4):292-301.

19. Sabatier R, Calderon B, Lambaudie E, et al.: Prognostic factors for ovarian epithelial cancer in the elderly patients with ovarian cancer: a case-controlstudy. Int J Gynecol Cancer 2015;2585):815-822.

20. Fourcadier E, Tretarre B, Gras-AygonC, et al.: Undertreatment of elderly patients with ovarian cancer: a population based study. BMC Cancer 2015;26;15:937.

21. Liang XJ, Shen J. Adverse events risk associated with angiogenesis inhibitors addition to therapy in ovarian cancer: a meta-analysis of randomized controlled trials. Eur Rev Med Pharmacol Sci. 2016 Jun;20(12): 2701-9.

22. Lee SP, Hsu HC, Tai YJ, et al. Bevacizumab Dose Affects the Severity of Adverse Events in Gynecologic Malignancies. Front Pharmacol. 2019; Apr 26;10:426.

23. Dion L, Mimoun C, Timoh KN, et al. Ovarian Cancer in the Elderly: Time to Move towards a More Logical Approach to Improve Prognosis - A Study from the FRANCOGYN Group. J Clin Med. 2020;9:1339; doi: 10.3390/jcm9051339

24. Falandry, C.; Savoye, A.M.; Stefani, L.; Tinquaut, F.; Lorusso, D.; Herrstedt, J.; Bourbouloux, E.; Floquet, A.; Brachet, P.E.; Zannetti, A.; et al. EWOC-1: A randomized trial to evaluate the feasability of three different first-line chemotherapy regimens for vulnerable elderly women with ovarian cancer (OC): A GCIG-ENGOT-GINECO study. J Clin Oncol. 2019;37 (Suppl. S15):5508.

25. Mutsea A, Wimberger P, Oskay-Oezcelik G, et al. Impact of age on the safety and efficacy of bevacizumab (BEV)-containing therapy in patients (pts) with primary ovarian cancer (OC): analysis of OTILIA German non-interventional study on behalf of the NorthEastern German Society of Gynaecological Oncology Ovarian Cancer Working Group. Ann Oncol 2016; 27:296-312.

26. Amadio G, Marchetti C., Villani ER, et al. ToleRability of bevacizumab in elderly ovarian cancer patients (TURBO study): a case-control study of a real-life experience. J Gynecol Oncol2020;31(1).

27. Sorio R, Roemer-Becuwe C, Hilpert F, et al. Safety and efficacy of single-agent bevacizumab-containing therapy in elderly patients with platinum-resistant recurrent ovarian cancer: Subgroup analysis of the randomized phase III AURELIA trial. Cynecol Oncol. 2017; 144(1):65-71.

28. Beinse G, Emile G, Cessot A, et al. A Real-Life Experience of bevacizumab in Elderly Woman with advanced Ovarian Carcinoma. Int J Gynecol Cancer.2016 Sep:26(7):1196-1200. 
Sažetak

\title{
PODNOŠLJIVOST BEVACIZUMABA U BOLESNICA STARIJE DOBI OBOLJELIH OD RAKA JAJNIKA: ISKUSTVO ZAVODA ZA GINEKOLOŠKU ONKOLOGIJU U KLINIČKOM BOLNIČKOM CENTRU ZAGREB
}

\author{
K. Katić, V. Matković, J. Lešin, G. Vujić i A. Ćorušić
}

Uvod: Bevacizumab je rekombinantno humanizirano anti-VEGF monoklonsko antitijelo. Učinkovit je u liječenju epitelnog raka jajnika, kako u primarnom liječenju tako i kod pojave recidiva bolesti.

Incidencija raka jajnika povisuje se sa starosnom dobi. Unatoč velikoj prevalenciji raka jajnika u starijih osoba, liječenje starijih bolesnica često je manje agresivno nego kod mlađih bolesnica. U Hrvatskoj, od veljače 2017. imamo mogućnost liječenja bevacizumabom u bolesnica s epitelnim rakom jajnika, jajovoda i primarnim peritonealnim rakom, kako u prvolinijskom liječenju tako i u prvom recidivu bolesti. Cilj nam je bio istražiti sigurnost primjene bevacizumaba u bolesnica starijih od 65 godina.

Metode: Retrospektivno, analizirali smo medicinske podatke 65 bolesnica s epitelnim rakom jajnika, jajovoda ili primarnim peritonealnim rakom koji su započeli liječenje bevacizumabom u prvolinijskom liječenju u bolesnica s uznapredovalom bolesti kao i prvom recidivu bolesti u Zavodu za ginekološku onkologiju, KBC Zagreb u razdoblju 01.01.2017. do 31.12.2018. Bolesnice su bile podijeljene $u$ dvije skupine prema dobi: skupina 1 ( $\leq 65$ godina) i skupina 2 (>65 godina).

Rezultati: U naše istraživanje bilo je uključeno 65 bolesnica: 47 (72,3\%) bolesnica u skupini 1 u usporedbi s 18 (27,7\%) u skupini 2. Bevacizumab je primijenjen kod 39 (60\%) bolesnica kao prvolinijsko liječenje te kod 26 (40\% ) bolesnica kao drugolinijsko liječenje. Medijan dobi bio je 55 godina (raspon 35-65 godina) u skupini 1 i 70 godina (raspon 66-76 godina) u skupini 2. ECOG status 0 imalo je $44,7 \%$ bolesnica u skupini 1 u usporedbi sa samo $22 \%$ u skupini 2 . U vrijeme postavljanja dijagnoze, u starijih bolesnica zabilježen je barem jedan komorbiditet u 94,4\% slučajeva, u usporedbi s 42,6\% u skupini 2. Medijan broja apliciranih ciklusa bevacizumaba bio je 9 u bolesnica starijih od 65 godina, a 17 apliciranih ciklusa u skupini 1. U bolesnica koji su primale bevacizumab kao prvolinijsko liječenje, medijan intervala bez progresije bolesti (PFI) bio je 12 mjeseci u skupini 1 u odnosu na 7 mjeseci u bolesnica starijih od 65 godina. Slično tome, među onima koji su primali bevacizumab u drugoj liniji liječenja medijan PFI bio je 9 mjeseci u mlađih bolesnica u odnosu na 1 mjesec u bolesnica starijih od 65 godina. Pojava ne-hematoloških nuspojava nije se povećala u starijih bolesnika; 51,1\% bolesnica u skupini 1 prijavilo je neku ne-hematološku nuspojavu nasuprot samo $27,8 \%$ u starijih bolesnica.

Zaključak: Naše iskustvo liječenja bolesnica bevacizumabom pokazuje dobre rezultate s prihvatljivom toksičnošću, a naše istraživanje sugerira da je primjena bevacizumaba sigurna i podnošljiva i u bolesnica starijih od 65 godina.

KLJUČNE RIJEČI: rak jajnika, bevacizumab, terapija, starije bolesnice 